\title{
Analisis Hukum Islam terhadap Harta bersama dalam Kompilasi Hukum Islam
}

\author{
Ilham Akbar Syarif, Shindu Irwansyah, Ilham Mujahid \\ Program Studi Hukum Keluarga Islam, Fakultas Syariah, Universitas Islam Bandung \\ Jl. Tamansari No. 140116 \\ ilhamstd17@gmail.com,2 Shinduirwansyah@unisba.ac.id, ilhammujahidgunawan@gmail.com
}

\begin{abstract}
Abstarct-The joint asset in marriage is a legal product that may be appropriate or not in accordance with the principles of Islamic law, KHI is structured as referring to several legal sources: Islamic law, Western law, customary law, national law. Shared property as one of KHI's substance needs to be traced to the extent of its consistency on Islamic law. From the background above the problem is obtained, How is legislation under Islamic law? How are the treasures together in KHI according to Islamic law? The purpose of research is to know about legislation according to Islamic law, To know the joint treasures in KHI according to Islamic law legislation. The research methods used are library studies. This type of research is qualitative research. Results of the study: Legislation of Islamic law is the benchmark or reference to enforce a rule according to Islamic shariah, The joint treasures in KHI conform to the principles of legislation of Islamic law which contains principles of deity, justice, equality, deliberation, freedom, amar Ma'ruf nahi munkar, tolerance, and Ta'awun
\end{abstract}

Keywords-mutual property, Islamic law, legislation, KHI

Abstrak-Harta bersama dalam perkawinan merupakan produk hukum yang bersifat ijtihadi yang mungkin sesuai atau tidak sesuai dengan asas-asas legislasi Hukum Islam, KHI disusun merujuk kepada beberapa sumber hukum: Hukum islam, Hukum Barat, Hukum Adat, Hukum Nasional. Harta Bersama sebagai salah satu substansi KHI perlu ditelusuri sejauh mana kekonsistensinya terhadap hukum islam Dari latar belakang di atas didapatkan rumusan masalah: Bagaimana legislasi menurut hukum islam? Bagaimana harta bersama dalam KHI menurut legislasi hukum islam? Tujuan penelitian yaitu untuk mengetahui tentang legislasi menurut Hukum Islam, untuk mengetahui Harta Bersama dalam KHI menurut legislasi hukum islam. Metode penelitian yang digunakan adalah studi pustaka. jenis penelitian ini adalah penelitian kualitatif. Hasil penelitian: legislasi hukum islam adalah tolak ukur atau acuan untuk memberlakukan suatu aturan menurut Syariat Islam, Harta Bersama dalam KHI sesuai dengan asasasas legislasi Hukum Islam yaitu memuat asas ketuhanan, keadilan, persamaan, musyawarah, kebebasan, amar ma'ruf nahi munkar, toleransi, dan ta'awun KHI

Kata kunci -Harta Bersama, Hukum Islam, Legislasi,

\section{PENDAHULUAN}

Harta bersama adalah harta benda yang dihasilkan oleh pasangan suami istri bersama-sama selama masa perkawinan masih berlangsung. Yang tidak termasuk dalam kategori harta bersama adalah harta yang diperoleh atau dihasilkan sebelum masa perkawinan mereka, biasa disebut dengan harta bawaan (seperti halnya harta warisan) atau harta milik pribadi yang diperoleh setelah masa perkawinan yang biasa disebut harta perolehan (harta hibah, hadiah, sedekah).

Pada dasarnya tidak ada percampuran harta kekayaan dalam perkawinan antara suami dan istri (harta gono-gini). Konsep harta bersama pada awalnya berasal dari adat istiadat atau tradisi yang berkembang di Indonesia. Konsep ini kemudian di dukung oleh hukum islam dan hukum positif yang berlaku di negara kita. Sehingga, dapat di katakan ada kemungkinan telah terjadi suatu percampuran antara kekayaan suami dan kekayaan istri (alghele gemeenschap van goederen) dalam perkawinan mereka. Percampuran harta kekayaan (harta bersama) ini berlaku jika pasangan tersebut tidak menentukan hal lain dalam perjanjian perkawinan.

Pembahasan tentang harta bersama dalam kitab-kitab fikih yang ditulis oleh fukaha mazhab tidak ditemukan. Hal ini dimungkinkan karena Al-qur'an dan Hadis tidak membahas secara khusus mengenai pelembagaan harta bersama dalam suatu ikatan perkawinan. Sejauh ini hanya ditemukan ayat-ayat Al-qur'an yang membahas masalah harta benda secara umum yaitu pada surat An-nisa ayat 32

Dari latar belakang tentang harta bersama yang peneliti paparkan di atas Hukum Islam mengatur tentang harta bersama., meskipun memang hanya mengambil dalil ijmali.

Oleh sebab itu peneliti tertarik dan hendak meneliti bahwa harta Bersama dalam KHI sesuai atau tidak dengan teori perundang-undangan islam

Berdasarkan latar belakang yang telah diuraikan diatas, maka tujuan dalam penelitian ini adalah sebagai berikut:

1. Bagaimana legislasi menurut hukum islam?

2. Bagaimana harta bersama dalam KHI menurut legislasi hukum islam?

Jenis penelitian yang digunakan adalah kualitatif. Adapun metode penelitian yang digunakan adalah Analisis 
Deskriptif yang disajikan secara deskriptif. Sumber data yang digunakan data sekunder. data sekunder yaitu dari kajian terhadap KHI, buku-buku, kitab klasik, jurnal, Hisbah dan sumber lainnya yang menunjang dan berkaitan dengan Hara Bersama dalam KHI

\section{LANDASAN TEORI}

Ahmad rofiq dalam bukunya Fiqh Mawaris memberikan definisi mengenai harta Bersama yaitu harta yang diperoleh isteri selama dalam masa perkawinan. Apakah isteri secara formal bekerja dalam profesi tertentu di luar rumah atau sebagai ibu rumah tangga.

Harta perkawinan dalam hukum islam disebut syirkah, yaitu cara penyatuan atau penggabungan harta kekayaan seseorang dengan hartal orang lain. Al-qur'an dan hadis tidak membicarakan harta Bersama secara tegas, akan tetapi dalam kitab-kitab fiqih ada pembahasan yang dapat diartikan sebagai pembahasan harta Bersama, yaitu yang disebut syirkah atau syarikah.

Perkataan syirkah atau syarikah berasal dari Bahasa Arab, oleh karena masalah harta Bersama suami-isteri ini termasuk perkongsian atau syarikah, maka lebih dahulukan dibahas macam-macam perkongsian menurut para ulama yang akan di uraikan sebagai berikut:

\section{Menurut Mazhab Hanafi}

Syarikah dibagi dua bagian, yaitu syarikah milik dan syarikah uqud. Syarikah milik adalah perkongsian antara dua orang atau lebih terhadap sesuatu tanpa adanya akad atau perjanjian.

Syarikah uqud adalah perkongsian modal, tenaga, dan perkongsian modal tetapi sama-sama mendapat kepercayaan orang.

\section{Menurut Mazhab Maliki}

Syarikah dibagi dalam enam bagian, yaitu syarikah mufawwadhah (perkongsian tak terbatas), syarikah inaan (perkongsian terbatas), syarikah amal (perkongsian tenaga), syarikah dziman (perkongsian kepercayaan), syarikah jabar (perkongsian karena turut hadir), dan syarikah mudharabah (perkongsian dua laba).

\section{Menurut Mazhab Syafi'i}

Membagi syarikah dalam empat bagian, yaitu syarikah inaan (perkongsian terbatas), syarikah abdaan (perkongsian tenaga), syarikah mufawwadhah (perkongsian tak terbatas) dan syarikah wujuuh (perkongsian kepercayaan).

\section{Menurut Mazhab Hambali}

Syarikah dibagi dua, yaitu syarilkah fi mall (perkongsian kekayaan, dan syarikah fil uqud (perkongsian berdasarkan perjanjian).

Berdasarkan uraian di atas, disimpulkan bahwa harta Bersama dalam islam dapat dikatakan sebagai syarikah abdaan mufawwadhah. Dikatakan syarikah abdaan karena kemyataan bahwa pada umumnya suami-isteri dalam masyarakat Indonesia sama-sama bekerja membanting tulang berusaha untuk mendapatkan nafkah hidup keluarga sehari-hari dan sekedar harta simpanan untuk masa tua mereka dan peninggalan untuk anak-anak mereka sesudah mereka meninggal dunia.

Dikatakan syarikah mufawwadhah karena perkongsian suami tidak terbatas. Apa yang mereka hasilkan dalam masa perkawinan mereka termasuk harta Bersama, kecuali mereka terima sebagai hibah

\section{HASIL PENELITIAN DAN PEMBAHASAN}

Berdasarkan pembahasan sebelumnya, dikatakan suatu aturan yang hendak diberlakukan harus memuat asas-asas Legislasi Hukum Islam yaitu suatu aturan harus memiliki Asas Ketuhanan, Asas persamaan, Asas keadilan, Asas musyawarah, Asas kebebasan, Asas Amar Ma'ruf Nahi Mungkar, Asas al-Ta'awun dan Asas Toleransi.

Begitu juga mengenai konsep harta bersama dalam KHI yang diberlakukan, harus memiliki kesesuaian nilai dengan asas-asas legislasi hukum islam.

a. Asas Ketuhanan dalam Harta Bersama

Mengenai harta bersama tidak disebutkan sama sekali dalam sumber syariat islam (Al-qur'an dan Al-hadits), adapun pemberlakuan aturan harta bersama dianalogikan dengan syirkah atau syarikat berdasarkan dalil ijmali yang dijadikan sumber hukum Q.S. An-Nisa (4) ayat 32,

Meskipun dalil ijmaly (Q.S. An-Nisa [4] ayat 32) menjadi landasan hukum pemberlakuan aturan mengenai harta bersama atau "harta gono-gini" seakan dipaksakan, namun meskipun demikian dengan disandarkannya pada firman Allah Swt. ini menjadi bukti bahwa pembahasan dan pemberlakuan aturan tentang harta bersama memiliki asas ketuhanan, dalam artian harta bersama yang diatur dalam KHI mengacu pada firman Allah Swt. demi tercapai kemashlahatan umat Islam Indonesia khususnya.

b. Asas Musyawarah, Asas Persamaan dan Asas keadilan dalam Harta bersama

Asas Musyawarah Asas persamaan dan Asas Keadilan dalam Islam mengembangkan konsep persamaan dan keadilan secara konstitusi (musawah qanuniyyah) berdasarkan musyawarah, asas ini mengharuskan setiap individu yang bersangkutan (dengan aturan) di jamin hak dan konsekuensi hukumnya oleh undang-undang, meskipun dalam realita di masyarakat, tiap-tiap individu memiliki perbedaan fisik, intelektual, dan kekayaan.

Semua aturan yang termaktub dalam KHI, khususnya mengenai harta bersama berlaku untuk semua instansi pemerintahan dan masyarakat yang memerlukan. Hal ini sesuai dengan Instruksi Presiden Republik Indonesia No.1 tahun 1991 tanggal 10 Juni 1991 Tentang Penyebarluasan Kompilasi Hukum Islam dalam konsiderannya presiden menimbang:

Bahwa para Alim Ulama Indonesia dalam Loka Karya yang diadakan di Jakarta pada tanggal 2 sampai dengan 5 Februari 1988 telah menerima baik tiga rancangan buku Kompilasi Hukum Islam, yaitu Buku I tentang Hukum Perkawinan, Buku II tentang Hukum Kewarisan, dan Buku III tentang Hukum Perwakafan; 
Bahwa Kompilasi Hukum Islam tersebut dalam huruf a oleh Instansi Pemerintah dan oleh masyarakat yang memerlukannya dapat digunakan sebagai pedoman dalam menyelesaikan masalah-masalah di bidang tersebut.

Instruksi Presiden Republik Indonesia No.1 tahun 1991 tanggal 10 Juni 1991 Tentang Penyebarluasan Kompilasi Hukum Islam menjadi bukti bahwa penyusunan KHI berdasarkan musyawarah para Alim Ulama dan pemberlakuan aturan khususnya mengenai harta bersama berlaku untuk semua lapisan masyarakat yang membutuhkan yaitu berlaku untuk semua individu-individu yang terikat dengan akad perkawinan.

c. Asas Kebebasan dan Toleransi dalam Harta Bersama

Harta bersama diberlakukan salah satunya karena sudah menjadi kebiasaan yang diulangi oleh suatu masyarakat ('urf), contohnya, pembagian harta bersama dengan asas dua-pertiga untuk suami dan sepertiga untuk istri Di Beberapa daerah di Jawa Tengah disebut sakgendong-sakpikul yaitu suami mendapatkan dua pertiga dan istri mendapat sepertiga, di pulau Bali harta bersama dibagi berdasarkan asas "susuhun-sarembat", Begitu juga di kepulauan Bagai, terdapat azas dua-pertiga dan sepertiga tersebut. Akan tetapi dalam perkembangannya, azas "sakgendong-sakpikul" atau "susuhun-sarembat" dalam pembagian harta bersama makin lama makin lenyap.

Namun untuk mengantisipasi terjadinya permasalah di tengah masyarakat mengenai pembagian harta bersama, adat kebiasaan (urf) ini diadopsi oleh masyarakat sebagai hukum positif.

Begitu juga dalam Pasal 87 ayat (1), dijelaskan: "Harta bawaan masing-masing suami dan isteri dan harta yang diperoleh masing-masing sebagai hadiah atau warisan adalah dibawah penguasaan masing-masing, sepanjang para pihak tidak menentukan lain dalam perjanjian perkawinan". Menjadi bukti bahwa Harta Bersama yang diatur dalam KHI tidak menghalangi sepasang suami istri untuk membuat kesepakatan bersama mengenai ketentuan Harta Bersama.

d. Asas Amar Ma'ruf Nahi Mungkar, Asas alTa'awun dalam Harta Bersama

Ketentuan dan aturan harta bersama pada pasal 88 sampai 97, yaitu secara singkat dijelaskan:

Harta bersama terwujud sejak tanggal perkawinan dilangsungkan Sejak itu dengan sendirinya terbentuk harta bersama. Tanpa mempersoalkan siapa yang mencari. Tanpa mempersoalkan atas nama siapa terdaftar. Tanpa persetujuan bersama, suami atau istri tidak boleh mengasingkan atau memindahkan.

Hutang untuk kepentingan bersama dibebankan kepada harta bersama. dalam perkawinan serial atau poligami wujud harta bersama terpisah antara suami dengan masingmasing istri. Apabila perkawinan putus (mati atau cerai):

Harta bersama dibagi dua. Masing-masing mendapat setengah bagian. Apabila terjadi kematian, bagiannya menjadi tirkah. Apabila diperhatikan secara seksama dan dikaji lebih dalam memiliki nilai-nilai atau asas amar m'ruf nahi munkar dan asas al-taawun dimana hak-hak harta bersama diatur secara rinci dan jelas.

\section{KESIMPULAN}

Legislasi Hukum Islam adalah acuan atau tolak ukur mengenai kesesuaian atau ketidak sesuaian suatu aturan yang diberlakukan dengan nilai-nilai syariat islam yang dibuat dan diberlakukan atas musyawarahan yang mampu mewakili semua bagian masyarakat tanpa terkecuali dan tanpa membeda-bedakan.

a. Asas-asas Legislasi Hukum Islam adalah sebagai berikut:

1. Asas Ketuhanan

2. Asas persamaan

3. Asas keadilan

4. Asas musyawarah

5. Asas kebebasan

6. Asas Amar Ma’ruf Nahi Mungkar.

7. Asas al-Ta'awun.

8. Asas Toleransi.

\section{b. Harta Bersama Menurut Legislasi Hukum Islam}

Harta bersama dalam KHI menurut Legislasi Hukum Islam memiliki semua aspek nilai-nilai asas legislasi Hukum Islam, yaitu semua ketentuan dan aturan mengenai harta bersama dalam KHI memiliki semua asas legislasi hukum islam dari mulai asas asas ketuhanan, asas persamaan, asas keadilan, asas musyawarah, asas kebebasan, asas amar ma'ruf nahi mungkar, asas alta'awun dan asas toleransi.

\section{DAFTAR PUSTAKA}

[1] Happy Susanto, Pembagian Harta Gono-Gini Saat Terjadi Perceraian, Jakarta, Transmedia Pustaka, 2008

[2] Ahmad Rofiq, Fiqh Mawaris, ed. Revisi, Cet.4, Jakarta: PT Raja Grafindo Persada, 2001,

[3] H.A Damanhuri, HR, Segi-segi Hukum Perjanjian Perkawinan Harta Bersama, Mandar Maju, Bandung, 2007

[4] Soeharto, Instruksi Presiden Republik Indonesia Nomor 1 Tahun 1991 Tentang Penyebarluasan Kompilasi Hukum Islam, Jakarta, Juni 10.

[5] Kholil Nawawi, Harta Bersama Menurut Hukum Islam 